\title{
Makna Dalam Film Iklan
}

\author{
Arif Agung Suwasono \\ Dosen Program Studi Disain Komunikasi Visual \\ Fakultas Seni Rupa ISI Yogyakarta \\ ariefagungsuwasono@gmail.com
}

\begin{abstract}
Film, is a medium in communication, but the logic-signs in the film is unique. It have more visible and natural, and took away the coding message in communication. The power of film language is the sign that delivered, with visual icons and kinetic representation. Associated with commercial ad film, the arbitrary does not lie in the signs visually stunning, but on the meaning an associative obtained from the meanings sign coding ethnicity are semantically. What is served in the film ad is logic image of a commodities that delivered with a story that is frequently arbitrary, as a consequence of the ways in which advertise.
\end{abstract}

Keywords: Film, Visual Representation, Advertising.

Relevance to Visual Communication Design Practice: The messages and information carried by those ads compete fiercely one another. To win the competition, TV ads need to be designed with the correct strategies. To be able to set the most effective strategy, the designers have to learn and understand the logic of signs exist in a TV commercial.

\section{PENDAHULUAN}

Josep M. Boggs, dari universitas Kentucky, mengatakan, film kenyataannya sering merubah apa yang dilihat oleh penonton, seakan-akan apa yang dilihatnya menjadi sedemikian indah dari pada kenyataan yang ada, In fact, by creating images that are bigger than life, films have sometimes been made to seem more real than reality ${ }^{1}$. Obyek-obyek yang ditangkap dari sudut pandang kamera dapat direpresentasikan melebihi dari apa yang pernah dilihat manusia, bahkan pengalaman estetis yang didapatkan oleh

\footnotetext{
${ }^{1}$ Joseph M. Boggs, The Art of Watching Films, a guide to film analysis, The Benjamin/Cimmings Publishing Company, Inc., Canada, 1978, p., 3
}

pemirsa, diterima atau dapat dinikmati melebihi dari apa yang pernah difikirkannya. Panorama akan tampak sedemikian indah, suasana pedesaan akan tampak sejuk, bahkan sampai suasana malam akan tampak sedemikian mencekam.

Meskipun demikian, Boggs melanjutkan bahwa film pada dasarnya hanyalah medium, sebagai sarana komunikasi. Dia adalah alat seperti halnya peralatan seni yang dimiliki oleh seniman.

"The camera and its film are only the tools used by the filmmaker-no more important in their own way than the artist's brush, oils, and canvas, or the sculptor's hammer, chisel, and marble slap. It's not, after all, the nature of the 
tools that determines whether a finished product is a work of art, but the nature of the human mind behind those tools-its sensitivity, its creative power, its artistic vision, and, even more important, its ability to communicate the essence of that vision through the skillful use the medium's tools". 2

Film hanyalah sebagai medium untuk merepresentasikan ide. Film menjadi media atau kanvas layaknya seorang pelukis ketika dia hendak menuangkan pengalaman estetisnya. Kamera, lampu, properti, wardrobe hanyalah sekumpulan peralatan seperti cat, kuas dan palet bagi seorang pelukis. Hanya saja film bukanlah karya lukisan. Film mempunyai kekuatan teks serta kebahasaannya sendiri.

Di tangan sutradara yang handal, film menjadi karya artistik yang mampu 'menghipnotis' audiens bahwa apa yang dilihatnya menembus dimensi rasional kita, seolah-olah terbawa dalam lingkup emosional tertentu, dibawa ke arah realita-realita tertentu atau keyakinan-keyakinan tertentu, yang secara tidak sadar tak lagi menjadi realitas yang sesungguhnya. Dengan pengolahan penceritaan dan sudut pandang tertentu, kita secara tidak sadar akan ikut

\section{${ }^{2}$ Ibid}

berempati, merasakan gejolak emosi, mengikuti justifikasi dalam film, atau bahkan menjadi inspirasi hingga meyakini imajinasinya. Kita tidak pernah tahu apakah vampir itu memang takut dengan bawang putih, atau kenapa kita menangis, tertawa ataupun menahan amarah hanya karena melihat film. Kemampuan dan kreatifitas dalam mengatur cerita inilah menjadi salah satu kunci keberhasilan dalam penyajian film. Bahkan kita jarang melakukan resistensi dari realitas cerita film, karena kita mengikuti kebenaran-kebenaran dari cerita film yang disuguhkan meskipun kita tahu bahwa film tersebut adalah fiksi belaka.

Pembahasan tentang film sebagai karya seni memang mempunyai cakupan yang sangat luas, selain aspek-aspek yang dapat diidentifikasikan secara visual, sebagai sebuah pemahaman bahasa, film juga terkait dengan bahasa yang berhubungan dengan aspek suara, baik bahasa verbal maupun musik yang mengiringinya. Disamping itu film juga tidak dapat dilepaskan dengan realitas kebudayaan, pemahaman tentang keyakinan dan ideologi, serta teknologi. Ini semua menunjukkan betapa rumitnya untuk memahami realitas film, baik sebagai sarana dokumentasi, hiburan, komunikasi, promosi sampai dengan propaganda. Kendati demikian masyarakat dalam mengapresiasi film lebih banyak 
melihat bahwa film adalah representasi visual yang bercerita. Kita sering tak begitu mempersalahkan bagaimana seharusnya teknik pengambilan gambarnya, bagaimana sudut pencahayaannya, bagaimana adegannya, kode-kode sosial budaya yang melingkupinya, bahkan sampai dengan realitas kebenaran ceritanya. Kita akan melihat bagaimana suguhan cerita dari film itu sendiri untuk dilihat, dimengerti dan dinikmati. Dari sini dapat dilihat bahwa unsur penceritaan menjadi salah satu kunci keberhasilan sebuah film sebagai sarana komunikasi.

Selanjutnya dalam tulisan ini akan dibahas secara singkat bagaimana ruang lingkup penceritaan sebuah film dikaitkan dengan iklan. Film iklan sendiri adalah representasi yang cukup unik. Film iklan merupakan sebuah informasi yang sangat dibatasi oleh durasi tetapi mengemban tanggungjawab yang besar dalam setrategi pemasaran. Dengan durasi yang sangat singkat, dalam hitungan detik, film iklan harus dapat bersaing dengan film iklan lain sekaligus merebut perhatian pemirsa, mempengaruhi serta membentuk persepsi dalam jaringan semantik manusia.

\section{Realitas Film Iklan}

Film iklan adalah produk dari industri bisnis yang sangat potensial dalam segi pemasaran. Dia menjadi sebuah pesan yang senantiasa hadir di setiap program acara televisi. Bahkan sedemikian berdesak-desaknya film iklan di televisi, maka sering mengorbankan program acara atau tayangan lain menjadi discontinue. Sebuah program acara yang seharusnya runtut diterima sebagai sebuah informasi atau hiburan menjadi hilang daya penerimaannya dan suasana mentalnya ketika tiba-tiba film iklan muncul ditengahnya.

Film iklan sudah menjadi realitasnya sendiri sebagai bagian dari kehidupan media massa. Ada ketergantungan yang saling terkait antara media dan iklan yang saling menguntungkan. Tayangan film iklan pun menjadi sebuah program acara yang di formalkan, sebagai bagian dari sebuah program acara. Dia tidak hanya menjadi sekilas info, tetapi info sekilas, sebuah penekanan pada informasi yang memang harus ditonton. Dalam sebuah acara debat presiden dan cawapres di televisi, moderator bahkan sudah menjadikan info sekilas ini menjadi bagian dari acaranya. Film iklan sudah disejajarkan nilai informasi tayangnya dengan acara debat antara Prabowo Subianto dengan Joko Widodo. Tapi memang begitulah realitas film iklan di Indonesia, dia 
menjadi representasi yang akan terus menerus menerpa indera kita, menghadirkan suasana hasrat dan menjadi bagian dari informasi kita sehari-hari.

Realitasnya, iklan-iklan ini telah mendorong masyarakat untuk selalu mengidentifikasi produk untuk memenuhi kebutuhan-kebutuhannya. Bahkan seseorang professor dari Harvard berpendapat bahwa iklan menggoda orang untuk menghamburkan uang demi memiliki hal-hal yang tidak dibutuhkan manakala mereka seharusnya menggunakan uang itu untuk pekerjaan-pekerjaan umum $^{3}$. Pendapat ini memang tidak berlebihan, manakala iklan iklan ternyata dapat menstimulasi hasrat individu untuk mengkonsumsi produk sebagai bagian dari kebutuhan-kebutuhannya karena iklan bekerja dengan mengeksploitasi alam bawah sadar manusia, merangsang motif-motif psikologis manusia.

Tingkah laku atau perilaku konsumen, meliputi komunikasi, pengambilan keputusan, motivasi, pembentukan sikap, norma-norma sosial, penyesuaian terhadap norma dan etika dan reaksi antara manusia, telah menjadi dasar pengetahuan dari para pengiklan-pengiklan untuk direkonstruksi

\footnotetext{
3 David Ogilvy, Pengakuan Orang Iklan, Pustaka
} Tangga, Jakarta, 1990, hlm. 94 menjadi representasi iklan. Realitasnya adalah produk-produk massa semakin berlomba untuk saling mempengaruhi individu sebagai konsumen bahwa mereka mempunyai kebutuhan-kebutuhan yang sangat kompleks baik fisik sampai psikis.

Produk-produk yang senantiasa tidak mempunyai "arti" hendaklah diberikan nilai melalui atribut manusia, benda atau segala sesuatu yang sebelumnya telah mempunyai nilai. Ada semacam pertukaran nilai diantara penanda dengan petanda, yang diharapkan dapat membangkitkan motif kebutuhan dari individu ${ }^{4}$. Dari sini Judith ingin memberikan gambaran bahwa komoditi akan menjadi produk manakala di dalamnya sudah mencerminkan sebuah nilai yang melebihi dari nilai fungsionalnya. Manipulasi nilai yang direkonstruksikan dalam teks film iklan memang tak jarang memberikan gambaran sebuah realita budaya, sebuah fragmentasi nilai kultural yang memperlihatkan dimensi ideologis antar manusia.

Seiring kemajuan teknologi dan informasi, film tidak dipungkiri telah menjadi bagian yang tidak dapat dipisahkan dengan media komunikasi serta industri bisnis dan hiburan. Film telah menjadi sarana bisnis

\footnotetext{
${ }^{4}$ Judith Williamson, Decoding Advertisement, Ideology and Meaning in Advertising, Marion Bayars, London., 1991. hlm. 31
} 
sangat potensial dari pemilik modal dalam mempromosikan berbagai macam komoditi, bahkan film sendiri telah menjadi produk dalam industri hiburan dan informasi. Di sisi lain, film juga sering dipahami sebagai media komunikasi massa yang sarat dengan nilainilai kultural, mencerminkan budaya dari sekelompok masyarakat. Film cenderung merekam realitas yang tumbuh dan berkembang di masyarakat dan diproyeksikan di atas layar. Meskipun film adalah medium komunikasi, atau sebagai alat berkomunikasi, film sering diyakini mempunyai power yang sanggup menghipnotis manusia untuk menerima nilai budaya tertentu, atau sebagai sarana legimitasi ideologi yang terkandung di dalamnya.

Graeme Turner menyatakan bahwa film tidak hanya merefleksikan realitas, lebih daripada itu, film merepresentasi realitas atau menghadirkan kembali realita berdasar kodekode, konvensi serta ideologi dari kebudayaannya. Film, adalah teks monolog yang lahir dari pengolahan narasi yang diarahkan sebagai sebuah realita. Pada akhirnya film merupakan permainan logika tanda (sign-logic) yang penuh dengan nilai kultural. Dari sinilah, film dewasa ini sering dikaji dari beberapa disiplin ilmu, terutama sering disinggung dalam wacana culture studies. Film dipandang sebagai teks yang sarat dengan muatan nilai dan kode budaya serta sebagai medium ideologi yang hadir di tengah-tengah masyarakat. Film dianggap menyampaikan realitanya sendiri dengan dalih refleksi dari realitas sosial.

Film juga dipandang sebagai ajang kompetisi dalam menciptakan dunia pulasan (pseudoworld). Dalam wacana diskursus sosial, film dianggap sebagai agen sosial yang ikut bertanggung jawab atas immoralitas yang selama ini didengungkan sebagai media yang mendukung dan menggerus nilai-nilai kemanusiaan sebagaimana yang sering diwacanakan oleh para pemikir mazhab Frankfurt bahwa media massa termasuk film sering dianggap sebagai media yang melemahkan nilai-nilai kemanusiaaan secara kultural. Theodor Adorno dan Horkheimer sendiri menyatakan, bahwa dalam industri budaya, khususnya tentang keberadaan media massa telah membuat masyarakat menjadi semakin rendah, tidak lagi personal, melainkan dianggap mempunyai karakterisasi yang sama. Masyarakat diarahkan untuk mempunyai tingkat persepsi yang sama terhadap suatu realitas, entah tentang nilai selera, kebutuhan sampai dengan harkat hidup. Masyarakat dianggap sebagai makhluk yang pasif, bisa diarahkan dan dibentuk oleh teks-teks yang monolog, seolah-olah budaya mereka lebih rendah. Bukannya berdialog, 
media bahkan tidak melakukan apa-apa selain monolog yang membuat individu tetap berada dalam keadaan audien yang terasing dalam pengertian moral dan sosial. Bahkan menurut tokoh-tokoh kritis dalam mazhab Frankfurt ini, memandang bahwa film, terutama film iklan yang muncul di televisi telah mendorong terciptanya kapitalisme lanjut yang semakin memperkuat eksistensi kapitalisme dimana kecenderungan ini telah membuyarkan ramalan Marx bahwa kaptalisme akan hilang dengan sendirinya pada abad 20.

\section{Film Iklan dan Gender}

Film iklan memang menjadi perpanjangan sebuah bentuk kapitalisme, merangsang orang untuk berlaku dan bertindak konsumtif, memanipulasi kebutuhan, menjadikan hasrat sebagai strategi komunikasi, dan menampilkan retorika akan nilai-nilai idealisme, melemahkan daya kritis tentang kebutuhan serta menanamkan citra sebagai salah satu bagian dari perilaku sosial yang pada dasarnya adalah rekonstruksi dari ideologi kapitalisme, di mana fenomena ini menjadi kritik yang sering disuarakan oleh pemerhati dalam bidang culture studies.

Namun demikian, di balik representasi film iklan tersebut, terdapat makna kultural yang tidak selamanya menjadi pemahaman yang cenderung melemahkan eksistensi kemanusiaan, bahwa manusia harus menjadi dirinya sendiri tanpa terpengaruh oleh berbagai macam manipulasi kebutuhan yang dicoba untuk dinaturalisasikan lewat representasi film iklan. Manusia adalah makhluk yang berbudaya, mempunyai tatanan nilai yang diinternalisasi untuk mewujudkan keseimbangan dalam interaksi sosialnya. Tidak selamanya kode-kode sosial yang terdapat di balik representasi film iklan melemahkan eksistensi tatanan budaya, terutama yang berkaitan dengan gender, bahwa wanita diwacanakan sebagai individu yang subordinat. Bahkan aliran feminisme Barat menyuarakan bahwa dengan ketimpangan gender hanya mengakibatkan mereka selalu di bawah tekanan dari ideologi patriarki yang bersembunyi di tengah-tengah kapitalisme.

Untuk mengkaji representasi film iklan, hendaknya selalu dikaitkan dengan konteks budaya, sebuah nilai-nilai kehidupan yang berada di masyarakat, yang diinternalisasi sebagai manifestasi perilaku sosial. Nilai-nilai yang berkembang di masyarakat ini tentu tidak begitu saja digeneralisir pada seluruh tatanan masyarakat. Setiap kelompok masyarakat tentu mempunyai diskursus budayanya sendiri, sehingga apa yang dikritisi oleh para pemikir barat tentang dampak representasi iklan sebaiknya memang 
dihubungkan dengan konteks budaya, yang di dalamnya juga terdapat ideologi gender.

Iklan, sebagai produk informasi media massa, pada dasarnya adalah sekumpulan pesan yang dikomposisikan, disusun sedemikian rupa sehingga membentuk makna, sebuah makna yang terkadang menyentuh bias ideologi tertentu. Muatan ideologi ini tampak disebabkan kode-kode yang direkonstruksi dan diredifinisikan dalam iklan mengambil dari realitas maupun konstruksi sosial yang ada. Iklan tidak hanya sekedar pengorganisasian pesan yang menampilkan teks dan ilustrasi yang bersifat persuasif, membujuk dan memunculkan hasrat, akan tetapi di sisi lain iklan juga direpresentasikan dengan mengambil kodekode sosial sebagai bagian dari konstruksi sosial agar dapat diterima tanpa menimbulkan resistensi sosial.

Kendati demikian kode-kode ini cenderung bersifat implisit, meskipun ada beberapa iklan yang tidak termasuk di dalamnya, kode-kode dari realitas sosial ini akan tenggelam dalam permainan antara petanda dan penanda pada iklan itu sendiri. Muatan ideologis ini akan muncul manakala iklan diinterprestasikan dengan memahami doxa-doxa dari permainan sintaksis tandatanda pada iklan. Pengertian doxa di sini menurut Bourdieu adalah semacam pengetahuan yang digunakan untuk menunjukkan kualitas baik-buruk, salahbenar, indah-jelek, unggul-terbelakang, menyenangkan-membosankan dan sebagainya, untuk memenuhi dan melanggengkan dominasi maupun ideologi tertentu. Doxa pada iklan tidak semata-mata membentuk makna yang ideologis, namun juga makna yang ideologis tersebut dibungkus oleh kepentingan akumulasi modal. Ini berarti makna-makna ideologi yang diciptakan atau direpresentasikan iklan digunakan oleh kapitalisme untuk kelangsungan hidupnya. Sebaliknya perubahan dan perkembangan kapital memungkinkan diproduksinya makna-makna ideologis yang baru.

Sebagai ilustrasi, Thwaites menyatakan, bahwa kesuksesan seorang wanita bisnis sering direpresentasikan lewat media massa dengan stereotipikasi telah mengorbankan kehidupan keluarganya, kesuksesan dalam bidang bisnis (publik) telah memunculkan pandangan bahwa mereka telah melakukan pengingkaran dari "aturan-aturan tradisionalnya", yang bukan dikarenakan berkompetisi dengan kaum pria ${ }^{5}$.

\footnotetext{
5 Tony Thwaites, Lloyd Davis, Warmick Mules, Tools for Cultural Studies, an introduction, Macmilan, Australia, 1994, hlm. 156
} 
Adanya batasan-batasan tertentu dalam tingkat kompetisi ini secara langsung akan menyentuh dominasi patriarchal ideology. Akan tetapi 'sisi buruk' yang dialamatkan pada wanita tidak dikemas atau ditunjukkan dalam iklan. Hal ini dikhawatirkan akan menimbulkan resistensi sosial atau bahkan mungkin revolusi sosial. Wanita sukses, adalah sebagai gambaran bahwa marginalisasi terhadap wanita pada peran publik sudah berkurang. Wanita sukses, dan mulai berperan dalam ruang publik, merupakan tuntutan yang akomodatif bagi kesetaraan gender. Akan tetapi, tetap tidak menunjukkan bahwa kesuksesan itu bukan hasil dari kompetisi dengan kaum pria yang diideologikan sebagai penguasa ruang publik dalam ideologi patriarki, sedangkan wanita lebih berperan dalam ruang domestik. Dengan demikian wanita karir atau wanita bekerja dalam wilayah publik pun, jarang yang digambarkan sebagai pengendali kebijakan atau menempati posisi-posisi yang strategis. Fenomena ini menunjukkan adanya penghargaan dan kebebasan terhadap wanita untuk berperan dalam ruang publik akan tetapi tidak digambarkan sangat berperan, karena masih kuatnya dominasi ideologi patriarki.

Realitas sosial yang menunjukkan ideologi gender ini diredefinisikan oleh kapitalisme untuk menjadikan produkproduk industrinya semakin marak dan beragam sesuai dengan kelas-kelas ekonomi baru. Atribut kesuksesan, popularitas, keberhasilan dalam peran publik, sering dijadikan ragam citraan-citraan produk ataupun jasa dalam iklan. Sabun, kosmetika, parfum sampai dengan otomotif telah menggambarkan realitas wanita yang telah berperan dalam ruang publik dan melegimitasi adanya kebutuhan-kebutuhan terhadap produk-produk industri. Kapitalisme mendorong peningkatan hasil indutrinya dengan menggunakan kedok sentimen ideologi gender ini sebagai doxa yang diharapkan diterima oleh masyarakat sebagai hal yang bersifat natural. Kapitalisme terus berusaha meredam gejolak-gejolak sosial seperti gerakan feminisme untuk diakomodasi dan seolah mereka setuju dan terbuka dengan kritik atas tuntutan yang bersifat ideologis ini.

Akan tetapi di balik itu semua kapitalisme berusaha memperkuat sistem ekonominya dengan memanipulasi sentimen ideologi ini menjadi diskursus yang terjadi di dalam realitas sosial. Dengan demikian iklan bisa jadi mengambil kode untuk mencerminkan realitas sebagai cara untuk menaturalisasikan pesan tetapi di lain sisi iklan juga dapat meredefinisikan nilai-nilai ideologi baru 
sebagai sebuah makna yang hendak dinaturalisasikan. Iklan tidak hanya mencerminkan muatan ideologi, tetapi juga dapat menciptakan muatan ideologi yang hendak dinaturalisasikan oleh golongangolongan tertentu demi kelangsungan dominasi ideologi dan kepentingankepentingan tertentu, seperti kapitalisme.

\section{Film Iklan dan Konsumerisme}

Dalam psikologi periklanan, terminologi iklan sendiri mempunyai pengertian suatu penerapan komunikasi persuasi terhadap masalah pemasaran di mana tujuan dasarnya adalah pemberian informasi tentang suatu produk atau layanan dengan cara sedemikian rupa hingga pesan yang disampaikan diperhatikan, difahami, diingat dan diarahkan pada suatu tindakan dengan cara menimbulkan asosiasi asosiasi dan sikap yang tepat ${ }^{6}$. Lalu apa sesungguhnya film iklan itu. Jawaban dari pertanyaan ini tentu akan mengarah pada sudut pandang pemasaran itu sendiri, bahwa film iklan merupakan bagian dari upaya promosi untuk menjual produk, jasa, atau ide/gagasan dari sebuah organisasi atau korporasi.

Terminologi iklan begitu dominan dalam pengertian film iklan, sehingga menjadikan

\footnotetext{
6 Anne Anastasi, Bidang-bidang Psikologi Terapan, Rajawali Press, Jakarta, 1989, hlm. 439
}

film ini mempunyai karakteristik yang sangat kuat. Berbeda dengan film-film lain yang dibedakan menurut tema atau genrenya, film iklan adalah film yang berisi komunikasi persuasive yang memang sengaja dirancang sebagai bagian dari komunikasi pemasaran. Dengan demikian maka kepentingan untuk mendapatkan feedback, dalam arti masyarakat mengikuti apa yang diinginkan oleh korporasi menjadi tujuan utamanya.

Di dalam industri kapitalis saat ini kegiatan untuk beriklan termasuk merancang film iklan telah menjadi hal cukup strategis. Televisi sendiri sebagai medium komunikasi, mempunyai coverage yang sangat luas, menjangkau hampir ke seluruh pelosok daerah. Hal ini dipandang cukup menguntungkan para pemasang iklan, Sekali disiarkan, akan menjangkau wilayah yang sangat luas. Bahkan untuk memasarkan mie instan saja, ada sebuah korporasi yang menghabiskan dana miliaran rupiah. Meskipun untuk beriklan di televisi sangat mahal akan tetapi kenyataannya film iklan saling berjejalan dalam siaran televisi. Akibatnya yang sering menjadi korban adalah program acaranya sendiri yang sering di 'cut' hanya untuk menyiarkan iklan. Hal ini disebabkan penghidupan broadcast memang bersumber dari belanja iklan. Untuk menarik sebanyak banyaknya para pemasang iklan, 
broadcast sering menggunakan sistem rating yang tentu saja mempunyai konsekuensi perbedaan tarif dalam setiap program acaranya.

Begitu dahsyatnya iklan-iklan saat ini hingga menjadi ujung tombak pemasaran komoditi massa dalam era kapitalisme. Masyarakat disodori berbagai representasi sosial yang menyajikan kebutuhan-kebutuhan ilusif yang dapat memuaskan selera, hasrat dan pilihan-pilihan untuk mengkomsumsi komoditas. Logika baru dalam kapitalisme cenderung mendukung masyarakat untuk mengkonsumsi produk lewat permainan penandaan melaui iklan-iklan yang pada akhirnya sering dicap sebagai sarana untuk merayakan konsumerisme, hedonisme dan gaya hidup. Pencerapan kita tentang realitas atau tentang kebutuhan sejati pada akhirnya telah bergeser dan didominasi oleh imajiimaji yang dihasilkan oleh periklanan. Masyarakat dengan tidak sadar dibentuk dan direkonstruksi untuk menjadi kelas-kelas konsumen baru, seakan-akan mereka mempunyai mekanisme sosial dan ideologi tertentu yang merupakan manifestasi dari pola pikir serta representasi sosialnya. Iklaniklan telah mendorong masyarakat untuk selalu mengidentifikasi produk untuk memenuhi kebutuhan-kebutuhannya. Bahkan seseorang professor dari Harvard berpendapat bahwa iklan menggoda orang untuk menghamburkan uang demi memiliki hal-hal yang tidak dibutuhkan manakala mereka seharusnya menggunakan uang itu untuk pekerjaan-pekerjaan umum ${ }^{7}$. Pendapat ini memang tidak berlebihan, manakala iklan iklan ternyata dapat menstimulasi hasrat individu untuk mengkonsumsi produk sebagai bagian dari kebutuhan-kebutuhannya karena iklan bekerja dengan mengeksploitasi alam bawah sadar manusia, merangsang motif-motif psikologis manusia. Tingkah laku atau perilaku konsumen, meliputi komunikasi, pengambilan keputusan, motivasi, pembentukan sikap, norma-norma sosial, penyesuaian terhadap norma dan etika dan reaksi antara manusia, telah menjadi dasar pengetahuan dari para pengiklanpengiklan untuk direkonstruksi menjadi representasi iklan. Realitasnya adalah produkproduk massa semakin berlomba untuk saling mempengaruhi individu sebagai konsumen bahwa mereka mempunyai kebutuhankebutuhan yang sangat kompleks baik fisik sampai psikis. Produk-produk yang senantiasa tidak mempunyai "arti" telah diberikan nilai melalui atribut manusia, benda atau segala sesuatu yang sebelumnya telah mempunyai nilai. Ada semacam

\footnotetext{
7 David Ogilvy, Loc.Cit., 1990, hlm. 194
} 
pertukaran nilai diantara penanda dengan petanda, ${ }^{8}$ yang diharapkan dapat membangkitkan motif kebutuhan dari individu.

Di sisi lain iklan-iklan juga bekerja dengan memainkan peran-peran normatif, hubungan sosial sampai dengan kode-kode sosial sebagai bagian dari budaya manusia. Inilah yang menyebabkan seakan-akan iklaniklan tidak mampu ditolak dan cenderung dibiarkan, diterima atau diingat untuk suatu saat ditindaklanjuti karena memang dibutuhkan sebagai bagian dari kehidupan dan gaya hidupnya. Bahkan Judith Willamson menyatakan bahwa periklanan adalah salah satu dari faktor budaya yang cukup penting, dalam membentuk dan merefleksikan kehidupan manusia sehari-hari9.

Pada kenyataannya film iklan yang ditayangkan di televisi mempunyai durasi sangat pendek, dalam hitungan detik, paling lama tak lebih dari 60 detik untuk tayangan per produknya. Hal ini tak lepas dari biaya sewa ruang pada media televisi yang sangat mahal, dihitung dengan ukuran detik, sehingga film iklan sendiri rata-rata juga ditayangkan dalam hitungan detik. Sekilas tentu kita bertanya apa yang dapat

\footnotetext{
${ }^{8}$ Judith Williamson, Loc.Cit., 1991, hlm. 31

${ }^{9}$ Ibid, hlm. 11
}

diceritakan oleh sebuah film yang mempunyai durasi sedemikian pendek tersebut. Kendati demikian film iklan adalah juga sebuah tayangan yang bercerita, sebagai sebuah unsur dalam film, yakni ada cerita yang disuguhkan, hanya saja fokus dari cerita yang direpresentasikan adalah sarana untuk menstimulasi daya tarik terhadap merek atau produk. Cerita dalam film iklan direkonstruksi untuk membentuk asosiasi tertentu terhadap merek. Yang terpenting bagaimana cerita dalam film iklan dapat membentuk sebuah kesadaran bahwa produk yang ditawarkan mempunyai nilai kebutuhan, yang layak untuk dikonsumsi.

Cerita dalam film iklan sebenarnya dapat dikaji lebih mendalam bahwa tanda-tanda yang disampaikan dan membentuk permainan teks tersebut pada dasarnya mempunyai nilai-nilai ideologi yang dicoba untuk dinaturalisasikan sebagai bagian dari strategi persuasif. Hal yang paling banyak dikritisi oleh para pengamat bahwa iklan itu sendiri salah satunya mengembangkan ideologi konsumerisme sehingga membawa perubahan hidup bagi masyarakat untuk menjadi konsumtif. Dalam pandangan kapitalis, ideologi konsumerisme merupakan nilai dan cara pandang bahwa makna kehidupan manusia hendaknya ditemukan 
dari apa yang kita konsumsi, bukan pada apa yang kita hasilkan. ${ }^{10}$

Herbert Marscue berargumen bahwa ideologi konsumerisme telah mendorong masyarakat untuk mempunyai kesadaran palsu dan bahwa kebutuhan ini bekerja sebagai satu bentuk kontrol sosial. Orangorang akan menemukan jiwa mereka pada komoditi yang mereka punyai atau gunakan. Ada semacam kontrol sosial yang dicoba untuk direkonstruksikan bahwa komoditi yang mereka punyai atau gunakan adalah semacam cermin status atau sebagai dasar penilaian diri mereka sendiri terhadap lingkup sosialnya. Bagi Marcues iklan mendorong kebutuhan palsu agar seseorang menjadi pribadi sesuai yang digambarkan dalam iklan, menjadi jenis orang tertentu dengan menggunakan tipe pakaian tertentu, mobil tertentu, minyak wangi tertentu, sabun tertentu, makan-makanan dan minuman tertentu dan barang-barang lainnya. Bahkan tak jarang daya kritis manusia dilemahkan menjadi pemuja tertentu seperti yang digambarkan dalam iklan dengan obyek pemujaan-obyek pemujaan (fetishisme) tertentu yang menggerakkan asosiasi tertentu pada produk sebagai barang yang hendaknya

\footnotetext{
${ }^{10}$ John Storey, Cultural Studies dan Kajian Budaya Pop, Jalasutra, Yogyakarta, 2008, hlm. 144.
}

dikonsumsi untuk memuaskan kebutuhan imajinernya. Wanita dan laki-laki distandarisasikan bentuk tubuhnya, bahwa idealisasi bentuk tubuh adalah seperti yang divisualisasikan dalam iklan, seolah-olah bentuk tubuh dengan standar tertentu menjadi pemujaan yang seharusnya diikuti oleh orang-orang dengan bantuan produk atau komoditi yang ditawarkan, seperti susu misalnya. Ideologi konsumerisme bisa dilihat sebagai salah satu strategi pengalihan dari pencarian tiada akhir tentang kebutuhan manusia, bahwa konsumsi adalah jawaban bagi semua 'problem' kita, atau konsumsi akan menjawab seolah-olah kita akan merasakan lengkap, utuh atau terpuaskan hasrat-hasrat terpendam kita. Konsumsi akan mengembalikan diri kita serasa utuh dalam kondisi imajiner yang diliputi kebahagiaan.

\section{Logika Pencitraan}

Kembali pada film iklan, bahwa film iklan itu sendiri dapat dilihat sebagai tanda, sebuah gambaran utuh tentang produk dalam bentuk sajian film. Namun demikian di dalam film iklan sebenarnya terdapat penanda dan petanda yang menghasilkan sebuah makna asosiatif terhadap produk. Hanya saja penanda dalam film iklan adalah sajian gambar dan suara yang bersifat motion atau bergerak menyerupai realita yang ada dan hidup. Film iklan hendaknya dipahami bahwa 
penanda-penanda yang divisualisasikan adalah gambar bergerak (motion picture) yang direpresentasikan melalui sudut pandang kamera dan dibatasi oleh waktu. Penandapenanda dalam film iklan adalah obyek visual yang dihasilkan dari lensa kamera film yang direkonstruksi sedemikian rupa dalam proses editing sehingga menghasilkan rentetan adegan-adegan yang bekerja sama untuk menghasilkan makna tertentu dan membentuk asosiasi terhadap merek produk.

Film iklan sendiri proses penyandiannya sangat berbeda dengan iklan-iklan lain khususnya yang bersifat statis. Pada media cetak misalnya, ikon yang terdapat dalam iklan adalah statis dan dapat dilihat tanpa ada keterbatasan waktu, sehingga dapat diinterprestasi lebih leluasa. Akan sangat berbeda dibandingkan dengan film iklan di mana sajian ikonis yang disampaikan hanya berdurasi sangat pendek dan tidak bisa diulang. Kita dapat melihat film iklan tersebut mungkin di program acara yang lain atau dalam segmen yang lain. Dengan demikian maka teks dalam film iklan harus dapat dengan cepat menyajikan fakta asosiatif terhadap merek produk, bahwa produk yang ditawarkan dapat memuaskan kebutuhan orang atau konsumen.

Di dalam film iklan, teks atau cerita yang dibangun di dalamnya pada dasarnya bersifat arbitrer, di mana penanda-penanda yang sekaligus menghasilkan petanda secara visual diarahkan pada pemaknaan asosiatif yang semena-mena terhadap merek produk. Produk sama sekali tidak mempunyai gambaran mental apapun. Produk hanyalah mempunyai nilai fungsi yang ditawarkan dan di hargai dalam sejumlah uang. Produk tidak membentuk kesadaran akan nilai kepuasan terhadap kebutuhan. Produk tidaklah membentuk hasrat, pemujaan bahkan gaya hidup. Produk hanyalah komoditas konsumsi yang diberi label atau merek yang diharapkan dibeli oleh orang karena tertarik dari cerita iklan yang disuguhkan. Hubungan antara teks dan produk inilah yang bersifat arbitrer. Jika Saussure mempermasalahkan bahwa dalam bahasa antara penanda dan petanda adalah hubungan yang bersifat semena-mena, maka demikian pula dalam film iklan bahwa teks dan produk atau gambaran tentang merek sebenarnya juga bersifat arbitrer. Kita tidak pernah membayangkan bahwa sebuah parfum yang diberi label tertentu dapat memikat sedemikian banyak wanita. Kita juga tidak pernah paham bahwa sebuah sabun dapat memberikan sensasi cinta. Sabun hanyalah produk untuk mandi. Kopi hanyalah minuman berkafein dan bukan produk yang berfungsi agar dihargai oleh lawan jenis atau membangkitkan sensasi 
harmonis. Produk hanyalah komoditas bermerek yang mempunyai nilai tukar financial selaras dengan biaya produksi dan biaya iklan yang diharapkan dibeli oleh masyarakat dan mendatangkan keuntungan tertentu.

Saussure juga menegaskan bahwa arbitrer yang terjadi antara penanda dan petanda dalam kebahasaan diakibatkan adanya kesepakatan kultural, maka dalam film iklan antara teks dengan produk terdapat arbitrer semata karena didorong untuk mempengaruhi pembaca, bukan terjadi adanya sebuah konvensi dalam konstruksi sosial. Arbitreraritas dalam film iklan terjadi adalah diupayakan untuk memacu angka penjualan, sehingga besar kemungkinan petanda yang dihasilkan tidak bersifat baku sebagai sebuah konvensi antara produsen dan pengiklan. Dia akan berubah seiring dengan langue dari struktur sosial masyarakat. Bahkan para produsen dan pengiklan dalam melihat realitas merek produk juga melihat konvensi yang dihasilkan adalah bersifat sementara, tergantung pada sisi mana orang dapat dipengaruhi dalam kurun waktu tertentu. Konvensi dalam film iklan terbentuk manakala produsen dan pengiklan bersamasama mengkreasikan sebuah image tentang produk yang dicoba untuk dinaturalisasikan kepada konsumen.
Realitas yang dibangun dalam teks atau cerita dalam film iklan adalah realitas semu (pseudoword), yang pada dasarnya untuk membentuk sebuah citra tertentu, membentuk asosiasi-asosiasi tertentu, yang membedakan dengan pencitraan dari produk lainnya. Logika yang dibentuk adalah logika konsumsi yang tidak lagi terikat dengan logika fungsi produk itu sendiri. Logika yang muncul adalah sebagai logika tanda (logic of sign) dan logika citra (logic of image), yang diarahkan agar orang tertarik untuk membeli. Keputusan membeli sudah tidak lagi berdasar pada nilai fungsional akan tetapi berkembang pada keputusan untuk membeli tanda, citra atau tema yang ditawarkan dibalik sebuah produk. Tanda-tanda tersebut dikonstruksi sedemikian rupa ke dalam berbagai komoditi sebagai upaya untuk membedakan diri, menyodorkan sebuah alternatif terhadap pemuasan suatu nilai kebutuhan yang pada dasarnya semu.

Kenyataan terhadap logika citra ini tidak dapat dilepaskan dari era kapitalisme baru yang mendudukkan manusia sebagai subyek, orang yang secara tidak langsung diakui keberadaannya untuk ikut menentukan keberhasilan pemasaran komoditi. Manusia diakui sebagai organisme yang yang mempunyai kebutuhan dan selera tertentu. Manusia diakui sebagai subyek yang ikut 
membentuk relasi sosial, kelas sosial dan gaya hidup. Setrategi inilah yang kemudian melahirkan cara berfikir atas konsep tentang pencitraan (imagology). Cerita dalam film iklan direkayasa untuk menanamkan gagasan atas citra. Substansi produk menjadi kabur, yang ada adalah citra dari suatu merek (brand). W.F.

Haug menyatakan bahwa komoditi ataupun produk di dalam masyarakat kapitalis akan berkaitan langung dengan domain citra, yaitu bagaimana pencitraan ini digunakan sebagai alat untuk mengendalikan masyarakat. Produk dijadikan sebagai wacana pengendalian selera, gaya hidup, tingkah laku, aspirasi, serta imajinasi-imajinasi kolektif masyarakat luas oleh masyarakat kapitalis lewat berbagai pencitraan agar tercipta sebuah hasrat membeli di mana ilusi dan manipulasi adalah cara yang digunakan untuk mendominasi selera masyarakat.

\section{Watak Ikonik}

Kendati teks atau cerita dalam film iklan mempunyai makna yang arbitrer dikaitkan dengan watak dan realitas produk, tandatanda ikonik yang terdapat pada film iklan pada dasarnya adalah hubungan penanda dan petanda yang tidak bersifat arbitrer, dia akan menyuguhkan gambaran ikonik yang menyerupai realitas yang dikonvesikan. Kasih sayang ibu kepada anak atau anggota keluarga dapat dipahami dengan gambaran mental ikonik yang ada melalui ilustrasi seorang ibu yang tersenyum, dengan mimik muka yang tulus, ceria dihadapan anak atau anggota keluarganya. Ketombe hilang dapat dipahami dengan ilustrasi adegan wanita atau pria yang tersenyum dengan rambut bersih hitam bebas dari ketombe. Gambar-gambar yang divisualisasikan merupakan ikonis bagi realitas yang dinotasikannya. Gambargambar yang divisualisasikan lewat adeganadegan dalam film iklan adalah watak ikonis dari logika cerita (logic of story) itu sendiri.

Tanda visual yang direpresentasikan lewat adegan-adegan dalam film adalah menyerupai watak ikonik yang disampaikan. Informasi atau pesan yang disampaikan akan tergambarkan dengan jelas dari tanda-tanda visual dalam adegan, mulai tanda-tanda ekspresi yakni petunjuk wajah (facial cues), gerak-geriknya (gestural cues), dan kedekatan antar karakter (proximity cues). Sebuah adegan yang dimaknakan sebagai adegan kegalauan karena bau badan (ketiak) akan diekspresikan dengan lugas dari karakter dengan adegan-adegan yang tidak mau mengangkat tangannya, berjalan tertunduk, malu didepan kawan-kawan atau koleganya, ekspresi muka yang selalu merengut, mengambil jarak dengan lawan jenis dan sebagainya. Ini semua adalah untuk 
menggambarkan pesan tentang betapa bau ketiak menjadi persoalan dalam pergaulan, dan pesan ini dapat ditangkap dari tandatanda visual yang dimunculkan lewat adeganadegan itu sendiri. Sebaliknya ketika sebuah produk deodorant mampu mengatasi bau badan ini, maka karakter akan berekspresi ceria, tidak malu mengangkat tangan dan seterusnya, yang menunjukkan gambaran mental dari watak ikonik tentang kepuasan. Rekonstruksi adegan-adegan karakter tersebut menggambarkan watak ikonik yang jelas tentang makna yang direpresentasikan. Watak ikonik ini pun tidak hanya berhubungan dengan ekspresi karakter, tetapi juga di perluas dari atribut-atribut lain yang ikut dihadirkan sebagai pelengkap tanda, sebagai pengorganisasian tanda yang integral membentuk makna. Properti, wardrobe dan setting pun disuasanakan sesuai dengan cerita yang direkonstruksikan. Interior dapur, ruang makan, ruang tamu, ruang kantor dan sebagainya adalah tanda-tanda ikonik yang mengkodekan suasana mental dari ruang aktivitas karakter. Bahkan visual efek dan animasi yang dihadirkan adalah semata untuk menunjukkan tanda ikonik yang menandakan gambaran mental yang didenotasikan. Bagaimana baju yang berubah jadi putih bersih, kulit yang menjadi kuning langsat, muka yang berubah menjadi putih berseri, akan memperkuat makna dari watak ikonik, sebagai sebuah promise dari logika cerita itu sendiri. Dalam tataran gambar bergerak, kode-kode gambar dalam film iklan dapat diinternalisasikan sebagai bentuk representasi mental yang bersifat ikonik. Sedangkan dalam aspek sintaksis, representasi mental yang bersifat ikonik ini diperluas dari teknik visual yang pada dasarnya adalah tata bahasa visual dalam film, yakni tentang sudut pandang pengambilan gambarnya (angle), mulai dari sudut pandang dekat (close up, medium close up), sampai dengan sudut pandang jauh (medium long shot, long shot), dan juga tentang pemotongan gambar, transisi yang digunakan dan durasi tiap shot, di mana secara teknis adalah gambaran mental dari logika tanda yang direpresentasikan berdasarkan logika cerita film iklan itu sendiri.

Dengan realitas watak ikonik ini, kemampuan untuk mentransfer pengalaman mental menjadi sangat naturalis. Tidak ada penyandian pesan dalam jaringan semantik manusia. Tidak ada lagi petanda yang sangat konotatif dalam mengartikulasikan sebuah adegan-adegan visual. Adegan dalam film iklan adalah realitas yang dikonvensikan, sehingga penafsiran terhadap adegan akan cenderung monosemik. Adegan dalam film iklan adalah tanda ikonik yang mengikuti 
logika ceritanya sendiri. Realitas pada adeganadegan film iklan hendaknya dipahami sebagai rangkaian tanda ikonik yang membentuk watak ikoniknya sendiri. Arbitreriaritas dalam film iklan muncul ketika hubungan antara penanda dan petanda dikaitkan dengan logika cerita dan produk yang diasosiasikan. Logika cerita dalam film iklan adalah sebuah konsep yang dipahami sebagai upaya untuk membentuk makna asosiatif, menciptakan citra tentang produk, membedakan diri dengan produk pesaing, dan menstimulasi alam bawah sadar manusia untuk selalu mengingat dan ditawarkan sebagai kebutuhan, dan inilah yang cenderung bersifat arbitrer, karena terkadang melampaui rasio manusia dan cenderung imajinatif. Sehingga iklan sering dikatakan sebagai sandiwara yang menawarkan kebutuhan-kebutuhan semu.

\section{Penutup}

Logika tanda dalam film iklan tentu tidak dapat dilepaskan dari simbol dan kode kultural yang melingkupinya. Seorang yang berdasi atau memakai jas, tentu menyimbolkan sebuah identitas tentang pekerjaan atau mungkin status sosialnya. Maka ketika tanda merepresentasikan sebuah identitas, maka kode budaya akan menjadi semacam referensinya, sebuah identitas yang mengacu pada rekonstruksi sosialnya. Hanya saja rekonstruksi sosial dalam film iklan terkadang memang mengambil fragmentasi kode budaya yang ada, tetapi tak jarang merupakan penggambaran tentang sebuah ide. Di sinilah ideologi tentang rekonstruksi sosial menjadi dasar penciptaan ide tersebut. Keharmonisan sebuah keluarga sering diperlihatkan dalam film iklan yang menawarkan komoditi untuk rumah tangga, mulai dari susu, bumbu masak, pengharum dan sebagainya. Penggambaran idealisasi ibu rumah tangga digambarkan cukup bertanggung jawab dengan sabun cuci sampai pembersih ruangan. Bahkan identitas yang digambarkan lewat tanda yang mengasosiasikan tentang kejantanan, kecantikan, sampai dengan gaya hidup akan menjadi tanda ikonik yang memberikan penafsiran tentang produk. Berger mengatakan bahwa tanda-tanda ikonik yang merepresentasikan identitas tersebut merupakan penafsiran yang diharapkan dipahami oleh orang lain ${ }^{11}$. Hubungan tanda dan penanda digambarkan sebagai cara untuk untuk mendeskripsikan sebuah identitas dan kode budaya.

\footnotetext{
${ }^{11}$ Arthur Asa Berger, Pengantar Semiotika, Tandatanda dalam Kebudayaan Kontemporer, Tiara Wacana, Yogyakarta, 2010, hlm. 109
} 
"Dengan memanipulasi tanda-tanda yang berhubungan dengan sikap-sikap tertentu, seseorang bisa menjadi hebat. Dengan menggunakan tanda-tanda tersebut harapan orang bisa berkembang terhadap lawan jenisnya, sebagaimana sesorang menjadi orang yang berarti. Sistem tanda ini dapat juga disebut sebagai 'model' atau 'kesan'. ${ }^{2}$

Identitas yang tergambarkan dalam tanda-tanda ini sebagaimana dalam paham kapitalis dapat juga menggambarkan kelas dalam struktur masyarakat, kelas dalam pergaulan, kelas dalam interaksi sosial, kelas dalam pekerjaan sampai dengan kelas status sosial dan gaya hidup. Sistem tanda sebagai model atau kesan ini memang di manipulasikan secara ikonik sebagai upaya gambaran mental terhadap asosiasi produk. Pada akhirnya suasana akan menghasilkan harapan dan sikap, inilah yang gambaran dalam film iklan.

\section{PUSTAKA}

[1] Anne Anastasi. (1989). Bidang-bidang Psikologi Terapan. Jakarta: Rajawali Press.

[2] Arthur Asa Berger. (2010). Pengantar Semiotika, Tanda-tanda dalam Kebudayaan Kontemporer. Yogyakarta: Tiara Wacana.

[3] David Ogilvy. (1990). Pengakuan Orang Iklan, Jakarta: Pustaka Tangga.
[4] John Storey. (2008). Cultural Studies dan Kajian Budaya Pop. Yogyakarta: Jalasutra.

[5] Joseph M. Boggs. (1978). The Art of Watching Films, a guide to film analysis. Canada: The Benjamin/Cimmings Publishing Company, Inc.

[6] Judith Williamson. 1991. Decoding Advertisement, Ideology and Meaning in Advertising. London: Marion Bayars.

[7] Tony Thwaites. (1994). Lloyd Davis, Warmick Mules, Tools for Cultural Studies, an introduction. Australia: Macmillan.

12 Ibid. 